\title{
Pelatihan Manajemen dan Pembukuan Dasar Bagi IKM Sanan Kota Malang
}

\author{
${ }^{1 *}$ Agung Winarno, ${ }^{2}$ Yuli Agustina, ${ }^{3}$ Trisetia Wijijayanti, \\ ${ }^{4}$ Madziatul Churiyah, ${ }^{5}$ Subagyo \\ Universitas Negeri Malang; Jalan Semarang 5 Malang \\ *Corresponding author: agung.winarno.fe@um.ac.id
}

\begin{abstract}
Abstrak
Tujuan dari kegiatan pelatihan manajemen dan pembukuan dasar di IKM Sanan Kota Malang ini adalah memberikan wawasan, pengetahuan, dan pendampingan bagi para pelaku usaha kripik tempe untuk membuat pembukuan sederhana sehingga mampu membuat pembukuan sendiri agar tertib dalam melakukan pencatatan keuangannya sehingga dapat terukur pengeluaran, pemasukannya dan keuntungan yang diperoleh serta dapat mengetahui perkembangan usahanya. Metode yang dilakukan adalah melalui sosialisasi, kegiatan pelatihan dan pendampingan kepada para pelaku usaha sampai dengan pelaku usaha mempraktekkan langsung pembukuannya secara riil. Hasil yang diperoleh dari kegiatan pelatihan ini adalah dapat meningkatkan pengetahuan dan keterampilan wirausaha di dalam membuat pembukuan sedehana sehingga meningkatkan motivasi di dalam bekerja. pelatihan pembukuan sederhana mendapat respon yang positif dan pelaku usaha mendapatkan pengetahuan dan keterampilan mengenai wawasan baru dalam menjalankan usahanya melalui pembukuan/pencatatan keuangan sederhana yang mudah diaplikasikan. Impikasinya adalah melalui pelatihan pembukuan sederhana pelaku usaha IKM Sanan Kota Malang mampu memahami cara berwirausaha yang baik melalui pencatatan keuangan.
\end{abstract}

Kata kunci-IKM Sanan, Malang, Manajemen, Pelatihan, Pembukuan Dasar.

\section{Abstract}

The purpose of basic management and accounting training activities at IKM Sanan Malang is to provide insights, knowledge and assistance for tempe chip business practitioners to make simple bookkeeping so as to be able to make their own bookkeeping in order to conduct financial records so that measurable expenses can be measured, the income and profits obtained and can find out the development of the business. The method used is through socialization, training activities and mentoring to business actors up to business practitioners directly practicing bookkeeping in real terms. The results obtained from this training activity are able to increase entrepreneur's knowledge and skills in making simple bookkeeping so as to increase motivation in working. simple bookkeeping training gets a positive response and businesses get knowledge and skills about new insights in running their business through simple financial accounting / records that are easily applied. The dream is through simple accounting training for IKM Sanan Malang entrepreneurs able to understand good ways of entrepreneurship through financial records.

Keywords - IKM Sanan, Malang, Management, Training, Basic Acoounting

\section{PENDAHULUAN}

$\mathrm{K}$ ewirausahaan merupakan salah ini masih menunjukan persentase yang satu faktor yang dapat mendorong sangat kecil, yaitu belum mencapai $2 \%$. peningkatan perekonomian Indonesia. Indonesia masih jauh tertinggal oleh Selain dapat meningkatkan devisa system System-negara tetangga yang memiliki melalui penanaman modal investor asing, jumlah wirausaha lebih tinggi, misalnya kewirausahaan juga dapat meningkatkan Singapura yang merupakan system dengan kreativitas dan kemampuan masyarakat jumlah wirausaha tertinggi di ASEAN, dalam menyalurkan ide dan kreasinya kemudian disusul oleh Malaysia. Indonesia melalui pemanfaatan sumber daya alam memiliki 
Agung Winarno dkk. / Jurnal Karinov Vol. 3 No. 1 (2020) 59 - 64

sumber daya alam yang sangat yang tersedia di Indonesia sehingga secara melimpah tetapi karena kurangnya inovasi tidak langsung, pengembangan dan kreativitas penduduk dalam kewirausahaan juga dapat membuka memanfaatkan sumber daya tersebut, lapangan kerja baru.

Selain itu, sistem pencatatan keuangan yang belum dilakukan dengan baik, mengakibatkantercampurnya harta pribadi dengan harta perusahaan, sehingga pelaku usaha tidak dapat melakukan monitoring terhadap arus keuangan usaha. Manajemen keuangan usaha kecil pada dasarnya tidak terlepas dari fungsi manajemen, yaitu meliputi kegiatan perencanaan atau planning, pengorganisasian atau organizing, pelaksanaan atau pengalokasian/actuating dan pengendalian atau controlling serta evaluasi (POAC) (Hasibuan, 2009). Rivai (2013) menyatan bahwa pencatatan laporan keuangan yang sistematis memiliki manfaatmanfaat, yaitu dapat memberikan informasi kas yang dapat dipercaya mengenai posisi keuangan usaha pada suatu saat tertentu, dapat memberikan informasi keuangan mengenai hasil usaha dalam satu periode akuntansi, dapat memberikan informasi-informasi yang dapat membantu pihak yang berkepentingan untuk menilai kondisi dan potensi suatu usaha serta dapat memberikan informasi penting lainnya yang relevan dengan pihak yang berkepentingan lainnya. Harahap (2015) menjelaskan bahwa jenis laporan keuangan usaha yang umum, yaitu neraca atau laporan laba/rugi atau hasil usaha, laporan arus kas,laporan perusahaan posisi keuangan yang mana jenis laporan tersebut akan menyajikan informasi tentang kondisi suatu perusahaan.

Berbicara masalah ekonomi kerakyatan nampaknya tidak terlepas dari pembicaraan tentang Industri Kecil Menengah (IKM), karena data BPS per akhir tahun 2006 menunjukkan bahwa 48.528 juta atau sebesar $99,99 \%$ dari unit usaha yang ada di Indonesia adalah mereka yang tergolong dalam IKM. Dari data tersebut dapat dikatakan bahwa menggerakkan ekonomi kerakyatan adalah identik dengan memberdayakan IKM. Pernyataan ini dapat memunculkan tesis bahwa jika ingin mengurangi kemiskinan dan pengangguran, maka IKM harus diberdayakan. Kelompok IKM mampu menyerap tenaga kerja lebih kurang $87 \%$ dari jumlah tenaga kerja produktif yang tersedia. Sedangkan sumbangannya terhadap PDB mencapai 53,3\%. Secara umum kontribusi IKM dalam PDB setelah krisis 1997 mengalami kenaikan hingga tahun 2003, namun tahun 2006 mengalami penurunan. Usaha menengah relatif stabil, dan usaha besar menunjukkan kontribusi yang terus meningkat.

Selain mempunyai potensi yang cukup besar, IKM juga mengalami berbagai kendala dalam pengembangannya. Sehingga kontribusinya terhadap GDP hanya sekitar 53,3\%, tidak sebanding dengan jumlahnya yang mencapai $99,9 \%$. Rendahnya kontribusi IKM ini sebagai akibat dari masalahmasalah yang dihadapi IKM selama ini. Beberapa hasil penelitian menunjukkan bahwa masalahmasalah di sekitar IKM adalah sebagai berikut (Siswoyo, 2008). Pertama, rendahnya kualitas SDM. Hal ini terkait dengan "human capital" dalam konteks pengembangan IKM. Istilah human capital atau sering disama-artikan dengan "intellectual capital" yang berarti mengacu pada pengetahuan dan kemampuan mengetahui (knowing capability) dari seseorang terhadap suatu fenomena tertentu. Rendahnya kualitas SDM ini berpengaruh terhadap berbagai masalah yang muncul di IKM. Misalnya, dalam aspek kreativitas dan inovasi. Kedua, lemahnya akses pasar IKM menyebabkan ia kalah bersaing dalam pasar. Walaupun telah dilakukan berbagai upaya atau stimulus oleh eksternal (pemerintah), namun jika respon peserta Pelatihan kurang, maka tidak akan merubah keadaan. Ketiga, rendahnya kemampuan IKM dalam mengakses modal dan memanfaatkan modal untuk meningkatkan value added IKM. Kesulitan IKM mengakses modal lebih disebabkan ketiadaan jaminan (collateral) dan pembukunan yang tidak sesuai dengan Standar Akuntansi Keuangan (SAK).

Realisasi dana bergulir baik melalui Lembaga Pengelola Dana Bergulir (LPDB) atau institusi lain, dan penyisihan laba BUMN untuk IKM, faktanya hanya menyentuh sebagian kecil IKM. Keempat, kebanyakan peserta Pelatihan masih berpandangan klasik, melihat usaha dalam jangka pendek dan statis, tanpa mau melihat ke depan berkaitan dengan pengembangan usahanya. Hal ini disebabkan rendahnya kualitas SDM (sebagai human capital), keterbatasan kemampuan berfikir strategis dan terbatasnya orientasi visi yang bersifat long term, sehingga memunculkan masalah struktural dalam pengembangan pengembangan dan pemberdayaan IKM. Kelima, program kemitraan yang ada selama ini tidak berhasil menaikkan margin usaha mikrokecil ini, karena selama ini usaha menengah dan besar dalam menyelenggarakan kemitraan umumnya lebih disebabkan oleh anjuran pemerintah semata, dan dilakukan sendiri tanpa pola pemberdayaan usaha mikro-kecil yang jelas. Kenyataan di atas menjadi pendorong agar IKM dibina dan Page 60 
dikembangkan secara berkesinambungan (sustainable development). Hal ini senada dengan pasal 3 Undang-Undang RI No. 20 Tahun 2008 bahwa Usaha Mikro, Kecil, dan Menengah bertujuan menumbuhkan dan mengembangkan usahanya dalam rangka membangun perekonomian nasional berdasarkan demokrasi ekonomi yang berkeadilan. Perhatian terhadap usaha pembangunan UKM di daerah menjadi prioritas pembangunan, Para penganjur industri yang pertama kali menunjukkan bahwa industri merupakan suatu sektor pemimpin (leading sector) karena industri tersebut merangsang dan mendorong investasi-investasi di sektor lain juga. Arsyad (1999: 55). Keterkaitan-keterkaitan ini akan terjadi jika potensi daerah berkembang akan mengakibatkan industri-industri pariwisata ikut berkembang, diantaranya adalah industri indigenous kerajinan rakyat, industri sovenir, industri makanan daerah serta jasa-jasa pendukung pariwisata seperti, tranportasi, penginapan dan lainnya. Selama ini, kota Malang selalu diidentikkan dengan apel. Julukan Kota Apel pun melekat erat pada wilayah yang terletak di Jawa Timur ini. Malang merupakan kota penghasil apel yang tak diragukan lagi kualitasnya. Apel Malang terkenal akan kesegaran dan rasa manis yang tiada duanya. Saat mengelilingi kota yang dikenal dengan nama Parijs van-Oost Java ini, akan dengan mudah menemui aneka pedagang yang menjual keripik apel dan buah-buahan lainnya di sepanjang jalan. Namun, selain pennghasil apel kota Malang sejatinya juga merupakan salah satu wilayah penghasil tempe terbesar di Indonesia. Bahkan, ada satu kampung yang secara khusus mendedikasikan diri sebagai wilayah penghasil keripik tempe.

Meskipun memiliki potensi yang luar biasa, akan tetapi masih ditemukan berbagai permasalahan dalam industry kripik tempe di Sanan Kota Malang. Manyoritas pengusaha masih menggunakan pembukunan pegelolaan organisasi yang konvensional. Oleh karena itu, perlu dilakukan kegiatan Pelatihan Manajemen dan Pembukuan Dasar Bagi IKM Sanan Kota Malang dengan Tujuan dari kegiatan pelatihan manajemen dan pembukuan dasar di IKM Sanan Kota Malang ini adalah memberikan wawasan, pengetahuan, dan pendampingan bagi para pelaku usaha kripik tempe untuk membuat pembukuan sederhana sehingga mampu membuat pembukuan sendiri agar tertib dalam melakukan pencatatan keuangannya sehingga dapat terukur pengeluaran, pemasukannya dan keuntungan yang diperoleh serta dapat mengetahui perkembangan usahanya.

\section{METODE}

Metode dalam implikasi pengabdian ini dengan menggunakan pelatihan dan pendampingan. Pelaksanaan kegiatan pelatihan pembukuan sederhana dilaksanakan di Koperasi IKM Sanan Kota Malang yang merupakan perkumpulan para pelaku usaha Kripik Tempe Kota Malang sebanyak 50 peserta. Alur pelaksanaan kegiatan pengabdian dimulai dari, 1) Tahap persiapan, yang terdiri dari tahap : (a) penyiapan bahan administrasi sesuai dengan kebutuhan pelaksanaan sosialisasi, (b) melakukan koordinasi dengan kedua pengelola IKM Sanan Kota Malang (c) menyiapkan materi pelatihan dan sarana prasarana, (d) menyiapkan narasumber yang memiliki kompetensi sesuai dengan target dan tujuan pelatihan, dan (e) menyiapkan jadwal sosialisasi menyesuaikan dengan perencanaan kegiatan yang telah terprogram, 2) tahap pelaksanaan, yang terdiri dari (a) melakukan pelatihan pembukuan sederhana bagi pemilik usaha (b) diskusi mengenai pemahaman wawasan dan keterampilan yang sudah peserta kuasai, tanya jawab dan 3) tahap pelaksana pelatihan dan praktek langsung bagi peserta dalam membuat pembukuan sederhana, 3) evaluasi kegiatan dengan memberikan pre test dan post test mengenai pelatihan pembukuan sederhana. Setelah itu adalah tahap monitoring untuk melihat hasil pencatatan keuangan pelaku usaha.

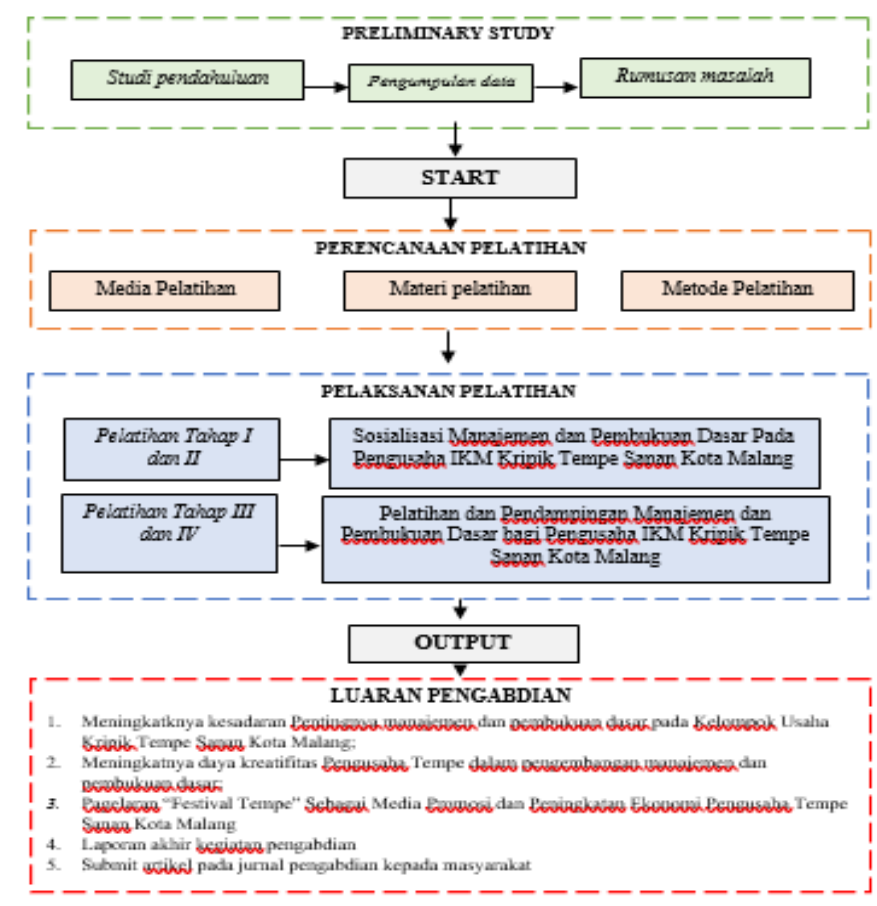

Gambar 1. Metode Pelaksanaan Pengabdian 
Agung Winarno dkk. / Jurnal Karinov Vol. 3 No. 1 (2020) 59 - 64

\section{HASIL DAN PEMBAHASAN}

Hasil yang diperoleh dalam pelatihan pembukuan sederhana bagi pelaku usaha IKM Sanan Kota Malang adalah masyarakat dapat memiliki pengatahuan dan keterampilan dalam memisahkan keuangan pribadi dengan usaha, serta para pelaku usaha IKM Sanan Kota Malang dapat mengetahui perkembangan usahanya melalui pembukuan yang baik dan sistematis. Hal ini sesuai dengan penelitian Subur dan Hasyim (2014:139) yang menjelaskan bahwa manajemen keuangan dalam menjalankan sebuah usaha kecil mikro adalah salah satu aspek penting dalam menentukan kesuksesan suatu usaha. Dengan manajemen yang baik maka akan diperoleh laba yang jelas jumlahnya, dan akan terjadi pengambilan keputusan yang tepat. Dengan demikian, laporan pembukuan sederhana sangat penting diperlukan dan diterapkan oleh pelaku usaha dan tidak menggabungkan uang pribadi dengan usang hasil usahanya. Adapun menurut Hasibuan (dalam Munizu, 2016 : 33) menjelaskan bahwa manajemen keuangan usaha kecil pada dasarnya tidak terlepas dari fungsi manajemen itu sendiri yang meliputi kegiatan perencanaan/ planning,pengorganisasian / organizin pelaksanaan/pengalokasian / actuating dan pengendalian / controlling serta evaluasi (POAC). Dengan demikian, apabila manajemennya baik akan 4 berpengaruh pula pada pengelolaan keuangan dari usaha tersebut. Rivai (2013) menyatan bahwa pencatatan laporan keuangan yang sistematis memiliki manfaat-manfaat, yaitu dapat memberikan informasi kas yang dapat dipercaya mengenai posisi keuangan usaha, dapat memberikan informasi keuangan mengenai hasil usaha dalam satu periode akuntansi, dapat memberikan informasi yang dapat membantu pihak berkepentingan untuk menilai kondisi dan potensi suatu usaha serta dapat memberikan informasi penting lainnya yang relevan dengan pihak yang berkepentingan lainnya. Dengan demikian, melalui laporan keuangan yang baik akan berpengaruh terhadap perkembangan usahanya sehingga dapat mengetahui laporan pengeluaran dan pendapatnnya. Selain itu, dapat meningkatnya pengetahuan tentang pentingnya mengelola keuangan usaha dan merencanakan keuangan agar dapat meminimalisir kerugian akibat kesalahan yang dilakukan sendiri. Dengan keuangan yang terkelola dengan baik diharapkan keuntungan usaha bisa meningkat dan bisa mengembangkan usahanya.

Sesuai dengan rencana yang telah ditentukan sebelum kegiatan pelatihan dilaksanakan, kegiatan pengabdian kepada masyarakat ini diawali dengan kegiatan administratif berupa perijinan, dan undangan peserta pelatihan. Peserta pelatihan ini merupakan usaha kecil dan mikro yang bergerak di bidang makanan/ kuliner yang merupakan paguyuban IKM Kampung Sanan. Kegiatan pelatihan terbagi menjadi 2(dua) bagian, yaitu pelatihan pembukuan keuangan sederhana dan pelatihan motivasi kewirausahaan, adapun pembahasannya adalah sebagai berikut: (1)Pelatihan motivasi kewirausahaan bertujuan untuk meningkatkan motivasi para pelaku usaha agar tidak mudah putus asa dalam melakukan usahanya, pemberian materi disajikan dalam bentuk powerpoint, menampilkan kisah sukses wirausahawan, serta sharing session untuk meningkatkan motivasi serta memperkaya ide-ide kreatif dalam melakukan inovasi; (2) Pelatihan pembukuan keuangan ini bertujuan untuk meningkatan ketrampilan dan pengatahuan para pelaku usaha, dapat memisahkan keuangan pribadi dengan usaha, serta para pelaku usaha dapat mengetahui perkembangan usahanya melalui pembukuan yang baik. Materi yang disiapkan dalam pelatihan pembukuan keuangan sederhana, yaitu meliputi: (a) Materi pembukuan keuangan sederhana secara umum. Dalam penyampaiannya menjelaskan bahwa pentingnya pembukuan keuangan dalam usaha kecil dan mikro, perlunya memisahkan keuangan pribadi dengan usaha agar pelaku usaha mudah menganalisis hasil usaha; (b) Laporan arus kas yang berfungsi menjelaskan tentang jumlah penerimaan dan pengeluaran kas perusahaan dalam satu periode beserta sumbersumbernya; (c) Laporan laba rugi yang berfungsi memberikan informasi tentang aktivitas bisnis perusahaan misalnya Penjualan, Beban, dan Laba atau Rugi Bersih; (d) Laporan perubahan modal yang berfungsi menggambarkan peningkatan atau penurunan aktiva bersih atau kekayaan selama periode yang bersangkutan berdasarkan prinsip pengukuran tertentu yang dianut; (e) Neraca yang berfungsi menjelaskan nilai Aset, Kewajiban dan Modal perusahaan pada suatu tanggal tertentu; (f) Penerapan materi pada soal-soal kasus usaha dan dibuat sesuai riil pada pelaku usaha IKM Sanan Kota Malang.

Kegiatan pelatihan ini tidak hanya satu arah, tetapi terjadi dua arah dengan adanya sesi diskusi. 
Diskusi berlangsung setelah penyampaian materi dengan tertib dan terarah. Pada saat diskusi peserta berperan aktif melakukan tanya jawab terkait dengan permasalahan yang dihadapi oleh pelaku usaha masing-masing. Dampak dan manfaat dari kegiatan pengabdian kepada masyarakat ini yaitu pelaku usaha paguyuban IKM Kampung Sanan dapat mengelola pembukuan keuangan usahanya dengan baik dan sistematis, sehingga dapat menghasilkan laporan keuangan seusai dengan standar yang berlaku, sehingga dapat membantu kelancaran bantuan dari pihak ketiga (misalnya Bank) yang pada akhirnya dapat membangun kekuatan UMKM sehingga tercapai kesejahteraan masyarakat Indonesia secara adil dan merata. Selain itu, penerapan pembukuan sederhana juga dapat menciptakan budaya disiplin di dalam perusahaan. Motivasi pelaku usaha diharapkan dapat meningkat ketika dihadapkan pada situasi kondisi usaha yang fluktuatif, khususnya di era sekarang ini.Hal ini dapat terukur dari rencana jangka menengah perusahaan dalam melakukan inovasi, baik dari segi pengembangan produk, maupun dari pengembangan sistem manajemen. Dengan meningkatnya jiwa kewirausahaan di lingkungan pelaku usaha makanan pada paguyuban IKM Kampung Sanan diharapkan dapat menjadi pelopor dalam menjadi icon kuliner olahan tempe kota Malang serta menjadi inspirasi bagi warga kota Malang lainnya, umumnya bagi seluruh rakyat Indonesia. Adapun kegiatan yang telah dilakukan dapat dilihat pada gambar berikut :

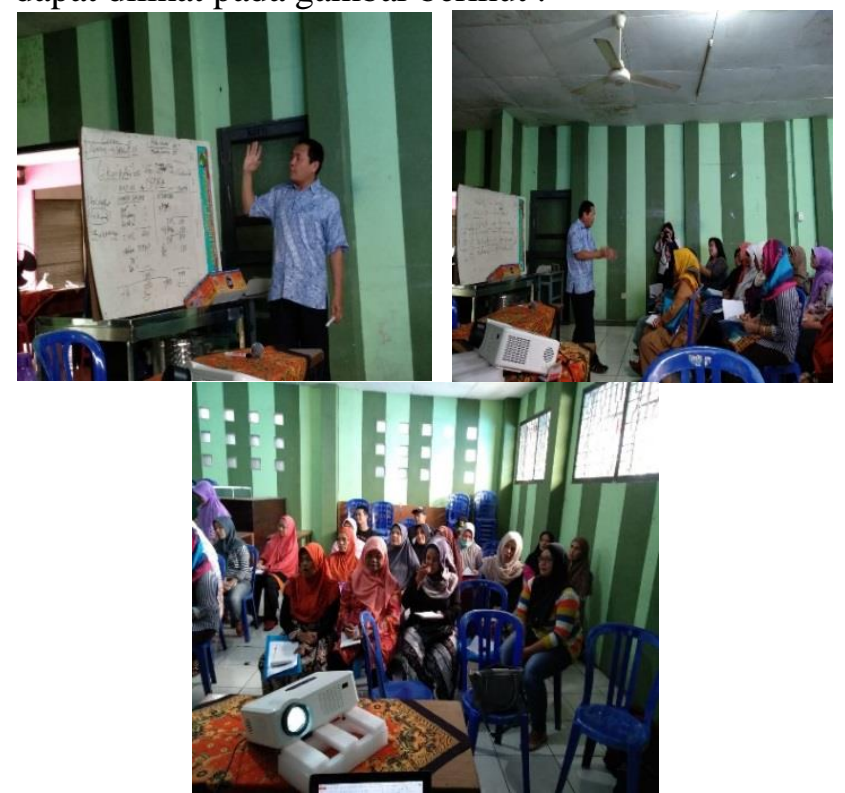

Gambar 2. Pelatihan tahap 1: narasumber memberikan materi kepada peserta

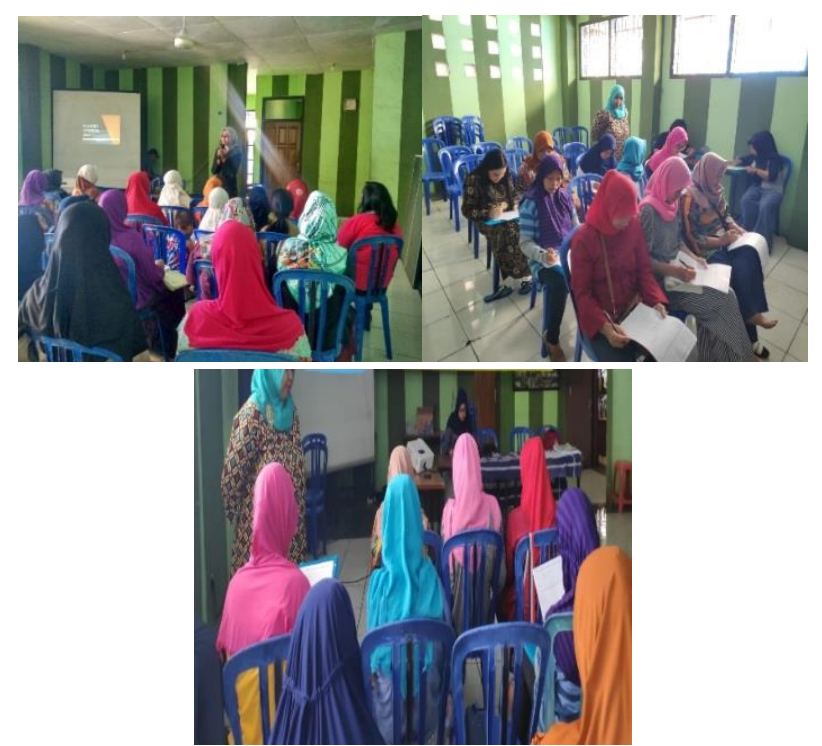

Gambar 3. Pelatihan tahap 2: Narasumber melakukan pendampingan saat kegiatan

Dampak dan manfaat dari kegiatan pengabdian kepada masyarakat melalui pelatihan pembukuan sederhana yaitu pelaku usaha IKM Sanan dapat mengelola pembukuan keuangan usahanya dengan baik dan sistematis, sehingga dapat menghasilkan laporan keuangan sesusai dengan standar yang berlaku, sehingga dapat membantu kelancaran bantuan dari pihak ketiga (misalnya Bank) yang pada akhirnya dapat membangun kekuatan usaha sehingga tercapai kesejahteraan masyarakat Indonesia secara adil dan merata. Selain itu, penerapan pembukuan sederhana juga dapat menciptakan budaya disiplin di dalam perusahaan. Berdasarkan pengamatan dari pelatihan pembukuan sederhana, memberikan respon positif bagi pelaku usaha IKM Sanan dan mereka sangat antusis di dalam pelatihan. Hal ini disebabkan karena melalui pelatihan ini dapat meningkatkan pengetahuan dan keterampilan wirausaha di dalam membuat pembukuan sedehana sehingga meningkatkan motivasi di dalam bekerja. Selain itu, sebagai tindak lanjut pelatihan dengan melakukan monitoring terhadap keberlanjutan kegiatan ini. Tidak menutup kemungkinan kedepannya bukan hanya memiliki laporan keuangan yang manual sederhana, namun kita dapat membantu mereka untuk membuat sistem yang laporan keuangan yang terkomputerisasi sehingga lebih memudahkan mereka. 
Agung Winarno dkk. / Jurnal Karinov Vol. 3 No. 1 (2020) 59 - 64

\section{SIMPULAN}

Kegiatan pengabdian kepada masyarakat pada pelaku usaha makanan IKM Sanan Kota Malang mendapat respon yang positif. Para pelaku usaha mendapatkan pandangan baru, mengetahui dan termotivasi dalam menjalan usaha yang baik melalui pembukuan / pencatatan keuangan sederhana yang mudah diaplikasikan serta memupuk motivasi kewirausahaan. Pembelajaran yang dapat diambil adalah dalam pengelolaan perusahaan, membutuhkan sistem yang terintegrasi yang saling terkait satu dengan yang lainnya. Artinya, dalam menjalankan usaha dibutuhkan komitmen yang tinggi dari pemilik usaha agar perusahaan untuk menjalankan sistem tersebut. Pembukuan keuangan sederhana tidak akan berjalan secara optimal tanpa adanya komitmen dari pelaku usaha untuk menjalankan sistem keuangan tersebut. Selanjutnya, Pembelajaran yang dapat diambil adalah dalam pengelolaan perusahaan, membutuhkan sistem yang terintegrasi yang saling terkait satu dengan yang lainnya.Artinya, dalam menjalankan usaha dibutuhkan komitmen yang tinggi dari pemilik usaha agar perusahaan untuk menjalankan sistem tersebut.Pembukuan keuangan sederhana tidak akan berjalan secara optimal tanpa adanya komitmen dari pelaku usaha untuk menjalankan sistem keuangan tersebut.

\section{DAFTAR RUJUKAN}

Harahap, S., S. (2015). Analisis Kritis Atas Laporan Keuangan. Edisi kesebelas, Rajawali Pers, Jakarta.

Hasibuan, Melayu S.P. (2009). Manajemen Cet III Jakarta :Bumi Aksara.

Maulani. Terra Saptina. (2016). Pelatihan Pembukuan Keuangan Sederhana dan Motivasi Kewirausahaan pada Kelompok Usaha Makanan RW 02 Kelurahan Neglasari Kecamatan Cibeunying Kaler Bandung. Jurnal Dharma Bhakti STIE Ekuitas, 1 (1), p.33

Munizu, M. (2016). Pengaruh Faktor-Faktor Eksternal dan Internal Terhadap Kinerja Usaha Mikro dan Kecil (UMK) di Sulawesi Selatan. Jurnal Manajemen dan kewirausahaan.

Rivai, V. (2013). Commercial Bank Mangement : Manajemen Perbankan dari Teori ke Praktek. Edisi 1. Cetakan 1. Jakarta : Rajawali Pers.
Siswoyo, D. (2008). Ilmu Pendidikan. Yogyakarta: UNY Pers.

Subur, Rahmad Santoso dan Hasyim Muhammad. (2014). Pelatihan Manajemen Keuangan pada pelaku Usaha Toko Kelontongan Dusun Puluhan Desa Banyusidi Pakis Magelang Jawa Tengah. Jurnal Inovasi dan Kewirausahaan, 3 (2), 139. 